\title{
PENGARUH PELAKSANAAN E KATALOG DALAM PENGADAAN BARANG/JASA PEMERINTAH TERHADAP UMKM
}

\author{
Muhammad Iqbal \\ Fakultas Ekonomi, Universitas Semarang, Semarang \\ muhammad.iqbal@usm.ac.id
}

\begin{abstract}
Abstrak
Tujuan dari penelitian ini adalah untuk menganalisis pelaksanaan e katalog dalam pengadaan barang/jasa pemerintah dan untuk mengkaji pengaruh pelaksanaan e katalog dalam pengadaan barang/jasa pemerintah terhadap Usaha Mikro, Kecil dan |Menengah (UMKM). Seiring pertumbuhan ekonomi Indonesia yang pesat disertai dengan pengembangan otonomi daerah, kebutuhan pemerintah akan penyelenggaraan pemerintahan turut meningkat. Kebutuhan pemerintah akan pembangunan sarana dan prasarana dapat sebagai penyediaan pelayanan publik harus dilaksanakan melalui proses pengadaan barang/jasa, Metode penelitian yang digunakan adalah yuridis normatif. Pelaksanaan pengadaan barang/jasa pemerintah dengan e katalog akan lebih terbuka, transparan dan efisien dengan memangkas proses dan waktu dalam pengadan barang/jasa pemerintah. Pelaksanaan e katalog dalam pengadaan barang/jasa pemerintah berpengaruh pada sektor UMKM, masih adanya pelaku industri kecil yang selama ini menjadi rantai distribusi barang/jasa. Melalui e katalog yang memutus rantai distribusi tersebut menyebabkan terhapusnya peran penyedia jasa kecil yang selama ini menjadi bagian dari rantai distribusi. Pemerintah telah mendorong pemanfaatan sistem e katalog bagi UMKM, salah satunya adalah partisipasi UMKM dalam produk lokal e katalog. Pada pelaksanaanya pemanfaatan sistem e katalog bagi UMKM masih kurang, terbukti dengan masih minimnya pemanfaatan sistem e katalog oleh UMKM karena masih terbatasnya modal dan informasi terkait penggunaan sistem e katalog.
\end{abstract}

Kata kunci : e katalog; UMKM; pengadaan barang/jasa 


\title{
THE EFFECT OF IMPLEMENTATION OF E CATALOGS IN PROCUREMENT OF GOODS / GOVERNMENT SERVICES TOWARD MSME
}

\author{
Muhammad Iqbal \\ Faculty of Economics, Semarang University, Semarang \\ muhammad.iqbal@usm.ac.id
}

\begin{abstract}
The purpose of this study is to analyze the implementation of e-catalog in the procurement of government goods / services and to examine the effect of the implementation of e-catalog in the procurement of government goods / services on Micro, Small and Medium Enterprises (MSMEs). As Indonesia's rapid economic growth is accompanied by the development of regional autonomy, the government's need for government administration also increases. Government needs for the construction of facilities and infrastructure can be as a provision of public services must be carried out through the process of procurement of goods / services, the research method used is juridical normative. The implementation of government goods / services procurement by e catalog will be more open, transparent and efficient by cutting down the process and time in the administration of government goods / services. The implementation of e-catalog in the procurement of government goods / services influences the MSME sector, there are still small-scale industry players who have been the goods / services distribution chain. Through the e-catalog that breaks the distribution chain, it causes the elimination of the role of small service providers that have been part of the distribution chain. The government has encouraged the use of the e catalog system for MSMEs, one of which is the participation of MSMEs in local e catalog products. In the implementation of the use of the e catalog system for MSMEs is still lacking, as evidenced by the still minimal use of the e catalog system by MSMEs because of the limited capital and information related to the use of the e catalog system.
\end{abstract}

Keywords: e catalog; MSME; procurement of goods /services 


\section{A. PENDAHULUAN}

Pengadaan barang dan jasa pemerintah merupakan aktivitas yang sangat penting dalam mewujudkan pembangunan. Dilihat dari berbagai perspektif, kemajuan indonesia tidak dapat dilepaskan dari aktivitas tersebut. Di bidang perekonomian, pembangunan sarana dan prasarana penunjang pertumbuhan perekonomian terwujud melalui mekanisme pengadaan barang dan jasa pemerintah Di bidang sosial, pengadaan barang dan jasa pemerintah untuk peningkatan fasilitas kesehatan, pendidikan, dan pengentasan kemiskinan juga membantu mengatasi sebagian masalah sosial. ${ }^{1}$ Seiring pertumbuhan ekonomi Indonesia yang pesat disertai dengan pengembangan otonomi daerah, kebutuhan pemerintah akan penyelenggaraan pemerintahan turut meningkat. Kebutuhan pemerintah tersebut dapat secara materiil maupun non materiil. Kebutuhan tersebut terwakili melalui proses pengadaan barang/jasa. $^{2}$

Guna mengikuti perkembangan teknologi dan informasi khususnya dalam sektor pengadaan barang/jasa pemerintah, untuk mendapatkan pengadaan barang/jasa pemerintah secara cepat, tepat, transparansi dan efisien, maka pemerintah mengeluarkan Peraturan Presiden No 54 Tahun 2010 tentang Pengadaan Barang/Jasa Pemerintah. Melalui Perpres tersebut telah diatur pengadaan barang/jasa pemerintah secara elektronik atau e-procurement. Perubahan tata cara lelang dari manual atau non e-tendering menjadi e-procurement pada tahun 2010 sedikit banyak memberikan dampak yang cukup signifikan dalam perbaikan proses pengadaan/barang/jasa. Terjadi peningkatan efisiensi

${ }^{1}$ Rio Pinondang Hasibuan, "Pengadaan Barang Dan Jasa Secara Elektronik Pada Dinas Koperasi Dan Umkm Kota Pekanbaru Tahun 2014”, Jurnal Online Mahasiswa (JOM) JOM FISIP Vol. 3 No. 2 - Oktober 2016, Fakultas Ilmu Sosial dan Ilmu Politik Universitas Riau, 2016, Pekanbaru, hal 2.

2 Amelia Iftitah Damayanti, Tjahjanulin Domai, Abdul Wachid, "Penerapan EProcurement Dalam Proses Pengadaan Barang/Jasa Di Kabupaten Malang”, Jurnal Administrasi Publik (JAP), Vol 1, No.2, Universitas Brawijaya, 2013, Malang, hal 140. 
penghematan uang negara dan meningkatnya transparansi dalam proses pengadaan barang/jasa dibanding sebelumnya. ${ }^{3}$

Pelaksanaan pengadaan barang/jasa pemerintah yang diatur dalam Perpres No.54 Tahun 2010 tersebut mengatur mulai dari perencanaan, penganggaran, persiapan lelang, penentuan harga perkiraan sendiri, pengumuman lelang, pelaksanaan lelang, pengumuman pemenang lelang, penandatanganan kontrak, pelaksanaan pekerjaan sampai dengan serah terima pekerjaan sampai dengan penyerahan pekerjaan. Efisiensi dan efektivitas proses pengadaan tersebut pada intinya sangat bergantung pada tata cara pemilihan penyedia. Pemilihan penyedia yang tepat akan menghasilkan barang/jasa yang sesuai dengan kebutuhan dan diterima pada waktu yang tepat. Pembelian barang/jasa yang sudah memiliki standar dan tersedia di pasar dalam jumlah yang memadai, dapat dilakukan secara elektronik,atau dikenal dengan istilah e-purchasing. Aplikasi e-purchasing menggunakan e-catalogue, yaitu sistem informasi elektronik yang memuat daftar, jenis, spesifikasi teknis dan harga barang tertentu dari berbagai penyedia barang/ jasa pemerintah.

Persaingan bisnis yang terjadi dewasa ini sangat ketat terlebih dengan adanya komitmen bangsa Indonesia dalam menyepakati AFTA maupun WTO maka usaha kecil dan menengah (UKM) sebagai salah satu pilar perekonomian Indonesia harus siap menghadapi persaingan dalam pasar bebas ini. Komitmen yang sudah disepakati ini menuntut penyikapan sedini mungkin oleh semua pihak, termasuk pelaku unit usaha kecil dan menengah (UKM) yang memiliki potensi terpendam. Dimana potensi yang dimiliki ini perlu digali dan dikembangkan untuk menghadapi era pasar bebas. Usaha kecil dan menengah (UKM) harus senantiasa didorong dan mengatasi berbagai kelemahan supaya mampu bersaing dan tidak jatuh tertindas oleh kompetitor. ${ }^{4}$

3 Zaenal Arifin, "Tindak Pidana Korupsi Dalam Proses Pengadaan Barang Dan Jasa Pemerintah”, Jurnal Respnsif Vol 5, No.5, Universitas Pembangunan Panca Budi, 2017, Medan, hal 56.

${ }^{4}$ Nuryanti, "Peran E-Commerce Untuk Meningkatkan Daya Saing Usaha Kecil Dan Menengah (UKM )”, Jurnal Ekonomi Vol 21, No 4 Desember 2013, Universitas Riau, 2013, Pekanbaru, hal 5. 
Pemerintah melalui Peraturan Presiden Nomor 4 Tahun 2015 tentang Perubahan Keempat Peraturan Presiden No 54 Tahun 2010 tentang Pengadaan Barang/Jasa Pemerintah telah mulai mengatur lebih dalam tentang pelaksanaan e katalog dalam proses pengadaan barang/jasa pemerintah yang dilaksanakan oleh Lembaga Kebijakan Pengadaan Barang/Jasa Pemerintah. Diberlakunya Perpres tersebut maka proses pengadaan barang/jasa pemerintah dapat dilaksanakan melalui e katalog. Menurut peraturan Presiden No 4 Tahun 2015, Katalog elektronik atau E-Catalogue adalah sistem informasi elektronik yang memuat daftar, jenis, spesifikasi teknis dan harga barang tertentu dari berbagai Penyedia Barang/Jasa Pemerintah.

Pelaksanaan pengadaan barang/jasa melalaui e katalog semakin kuat setelah terbitnya Peraturan Presiden Nomor 16 Tahun 2018 tentang Pengadaan Barang/Jasa Pemerintah. Pasal 50 ayat (5), bahwa pelaksanaan e-purchasing wajib dilakukan untuk barang/jasa yang menyangkut pemenuhan kebutuhan nasional dan/atau strategis yang ditetapkan oleh menteri, kepala lembaga, atau kepala daerah. Oleh karena itu, untuk barang/jasa yang diluar kriteria pemenuhan kebutuhan nasional dan/atau strategis, pengadaan barang/jasanya tidak wajib dilakukan melalui metode e purchasing.

Tentunya dengan menggunakan sistem e katalog ini akan timpul dampak positif dan negatif. Dampak positifnya yaitu adanya efisiensi belanja, pengadaan barang.jasa dapat dilaksanakan lebih cepat, penggina barang mempunyai keleuasaan memilih barang yang dibutuhkan melalui e katalog, adanya persaingan usaha yang sehat karena masing-masing penyedia menawarkan harga secara terbuka dan transparan.

Sedangkan dampak negatifnya yaitu mulai kacaunya penetapan harga barang, terputusnya rantai distribusi, melemahnya omset para pelaku usaha daerah hingga dampak terbesar dirasakan para pelaku usaha yang menjual produk-produk teknologi informasi (TI). 
Sayangnya, penerapan ini dinilainya mulai memutus rantai distribusi. Sebab, seluruh lembaga pemerintah diharuskan membeli keperluan belanja negara lewat online, yang mana sebenarnya untuk bidang Teknologi Informasi (TI) kurang sesuai, karena di membutuhkan instalasi jaringan dan juga dibutuhkan pelayanan purna jual yang harus cepat penanganannya, belum lagi jumlah produknya sangat banyak, sehingga pada kenyataannya produk-produk TI tersebut dikelola langsung oleh masing-masing Online Shop pengusaha TI nya, bukan oleh pihak LKPP. ${ }^{5}$

Data dari Kementerian Koperasi dan UMKM tahun 2018 menyebutkan bahwa jumlah pengusaha UMKM mencapai angka 64.194 .057 unit (99,9\%) dengan jumlah tenaga kerja mencapai 116.978.631 orang. Sedangkan golongan usaha besar mencapai 5.550 unit $(0,01 \%)$ dan jumlah tenaga kerja mencapai 3.619.507 orang. Dari data tersebut dapat disimpulkan bahwa sektor UMKM sangat mendominasi dari segi jumlah dan serapan tenaga kerja tetapi secara keseluruhan Pengusaha besar tetap lebih medominasi baik dari segi modal, asset dan perkembangan usaha.

Usaha Menengah Kecil dan Mikro (UMKM) juga ikut terdampak adanya pelaksanaan pengadaan barang/jasa pemerintah secara e katalog. Penyedia barang/jasa pemerintah yang sebagian besar merupakan UMKM berkurang omzetnya atau bahkan tutup usahanya karena tidak mampu bersaing dngan perusahaan besar dalam pelaksanaan e katalog ini. Perlu dipikirkan pola kemitraan yang digunakan dalam pelaksanaan e katalog dengan melibatkan penyedia barang jasa golongan kecil atau UMKM di daerah. Mengingat UMKM mempunyai peran yang sangat besar dalam perekonomian di Indonesia. Tujuan dari penelitian ini adalah untk menganalisis pelaksanaan e katalog dalam pengadaan barang/jasa pemerintah dan untk mengkaji pengaruh pelaksanaan e katalog dalam pengadaan barang/jasa pemerintah terhadap UMKM.

${ }^{5}$ https://analisadaily.com/berita/arsip/2017/10/28/440900/penerapan-e-katalogberdampak-pada-pelaku-usaha/, diunduh 6 Maret 2020, pukul 22.32 WIB 


\section{B. PERMASALAHAN}

1. Bagaimanakah pelaksanaan e katalog dalam pengadaan barang/jasa pemerintah?

2. Bagaimanakah pengaruh pelaksanaan e katalog dalam pengadaan barang/jasa pemerintah terhadap UMKM?

\section{METODE PENELITIAN}

Sementara itu Soeryono Soekanto menjelaskan arti penelitian adalah suatu kegiatan ilmiah yang berkaitan dengan analisa dan konstruksi yang dilakukan secara metodologis, sistematis dan konsisten. Beberapa pengertian tersebut dapat disimpulkan bahwa untuk tercapainya suatu hasil yang baik dari sebuah penelitian dibutuhkan suatu metode.

Penelitian hukum merupakan suatu kegiatan ilmiah yang didasarkan pada metode, sistematika dan pemikiran tertentu yang bertujuan untuk mempelajari satu atau beberapa gejala hukum tertentu dengan jalan menganalisanya. Kecuali itu maka juga diadakan pemeriksaan yang mendalam terhadap fakta hukum tersebut untuk kemudian mengusahakan suatu pemecahan atas permasalahan-permasalahan yang timbul di dalam gejala yang bersangkutan. ${ }^{6}$

Agar penelitian ini mampu mencapai tujuan dengan tetap mengacu pada standar ilmiah sebuah karya penelitian, maka penyusun menggunakan berbagai metode yang ada sebagai acuan dalam melakasanakan penelitian. Adapun diantara metode-metode yang digunakan oleh penyusun, sebagai berikut :

1. Jenis Penelitian

Penelitian ini bersifat yuridis normatif dimana penulis menelaah asas- asas serta doktrin yang berkaitan dengan pokok permasalahan secara mendalam. Penelitian yuridis normatif dalam penelitian hukum ini dilakukan dengan menelusuri, mengkaji, meneliti data sekunder (kepustakaan) yang berkaitan dengan materi penelitian. Pendekatan yuridis normatif merupakan pendekatan utama karena titik tolak penelitian ini adalah mengungkapkan kaedah-kaedah

\footnotetext{
${ }^{6}$ Soerjono Soekamto, Pengantar Penelitian Hukum, UI-Press, 2006, Jakarta, hlm. 43.
} 
normatif baik dari sumber yang didokumentasikan maupun informasi dari pihak bank dalam perjanjian kredit.

2. Jenis Data

Jenis data yang digunakan dalam penilitian ini adalah data sekunder. Data sekunder terdiri dari bahan-bahan hukum yang meliputi bahan hukum primer dan bahan hukum sekunder. Di dalam penelitian, sumber data terbagi menjadi 2 (dua) yaitu sumber data yang diperoleh secara langsung dari masyarakat yang selanjutnya disebut sebagai data primer dan data yang diperoleh dari bahanbahan pustaka yang kemudian disebut sebagai data sekunder

3. Cara Pengumpulan Data

Penelitian ini termasuk dalam penelitian kepustakaan, yaitu suatu penelitian yang bertujuan mendapatkan data sekunder dengan cara melakukan penelaahan terhadap peraturan perundang-undangan, literatur, karya-karya hukum dan bahan-bahan tertulis lainnya yang berkaitan dengan penelitian.

4. Alat Pengumpulan Data

Penelitian hukum normatif alat pengumpulan data dilakukan dengan melakukan studi pustaka terhadap bahan-bahan hukum primer, sekunder dan tersier. Alat pengumpulan data untuk memperoleh data yang dibutuhkan dilakukan dengan cara melakukan studi dokumen untuk mendapatkan gambaran secara umum mengenai hal-hal yang berhubungan dengan permasalahan yang diteliti.

5. Analisis Data

Data yang diperoleh dari penelitian kepustakaan selanjutnya dianalisis secara kualitatif. Data yang terkumpul kemudian dikelompokkan dan dipilah- pilah dicari yang relevan dan representatif yang berhubungan dengan permasalahan, diteliti dan dipelajari secara mendalam, ditelaah dan dipaparkan secara deskriptif kemudian dibuat kesimpulan dan diharapkan dapat menjawab permasalahan yang dibahas. 


\section{PEMBAHASAN}

\section{Pelaksanaan Pengadaan Barang/Jasa Pemerintah Melalui E Katalog}

Berdasarkan Peraturan Lembaga Kebijakan Pengadaan Barang/Jasa Pemerintah (LKPP) Nomor 11 Tahun 2018 Tentang Katalog Elektronik, e katalog adalah sistem informasi elektronik yang memuat informasi berupa daftar, jenis, spesifikasi teknis, Tingkat Komponen Dalam Negeri (TKDN), produk dalam negeri, produk Standar Nasional Indonesia (SNI), produk industri hijau, negara asal, harga dan informasi lainnya dari berbagai penyedia barang/jasa. E-katalog terdiri atas katalog elektronik nasional, katalog elektronik sektoral dan katalog elektronik lokal. E katalog meliputi barang, pekerjaan konstruksi dan/atau jasa lainnya.

Sementara itu, e-purchasing adalah tata cara pembelian barang/jasa melalui sistem e-katalog yang diselenggarakan dan dikembangkan oleh Lembaga Kebijakan Pengadaan Barang/Jasa Pemerintah (LKPP). E katalog dan e purchasing merupakan bagian dari pengadaan secara elektronik atau $e$ procurement. Telah terlaksananya sistem e katalog, maka seluruh instansi/kementerian/lembaga dan organisasi perangkat daerah (OPD) dalam pelaksanaan pengadaan barang/jasa tidak perlu melakukan proses pelelangan, namun dapat langsung memanfaatkan sistem ini dengan prosedur $e$ purchasing.

Berikut tahapan pemesanan barang/jasa yang dilakukan oleh Pejabat Pembuat Komitmen (PPK) : Nama paket pekerjaan pengadaan yang telah masuk dalam Rencana Umum Pengadaan (RUP), maka Pejabat Pembuat Komitmen dapat melakukan pemesanan dengan login ke aplikasi Sistem Pengadaan Secara Elektronik (SPSE) untuk selanjutnya PPK melakukan pembelian barang/jasa yang dibutuhkan melalui aplikasi e purchasing yang disesuaiakan dengan harga, spsesifikasi teknis, harga yang dibutuhkan untuk kemudian disesuaikan dengan data barang yang tercantum dalam e katalog. 
Setelah memilih jenis barang pesanan yang dikehendaki dan sesuai dengan spsesifikasi dan harga yang diminta, PPK kemudian mengirimkan permintaan pembelian barang/jasa kepada penyedia barang/jasa yang terdaftar dalam e katalog melalui aplikasi e purchasing. Permintaan pembelian dengan e puchasing ini bisa dengan melakukan negosiasi harga atau tidak tidak melakukan negosiasi.

Penyedia barang/jasa akan melihat permintaan pembelian tersebut kemudian memberikan persetujuan atas permintaan pembelian barang/jasa tersebut selambat-lambatnya tiga hari kerja sejak tanggal pemesanan barang/jasa. Persetujuan pembelian barang/jasa dari pihak penyedia secara otomatis akan ternotifikasi pada paket pembelian. PPK/Pejabat Pengadaan mengirimkan permintaan pembelian barang/jasa yang telah disetujui oleh penyedia melalui aplikasi e purchasing. PPK/Pejabat Pengadaan mengirimkan surat pesanan pembelian barang/jasa kepada penyedia pada sistem e katalog melalui aplikasi e purchasing, dan selanjutnya PPK/Pejabat Pengadaan dan penyedia melakukan persetujuan permintaan pembelian yang dilanjutkan dengan dilaksanakannya perjanjian pembelian.

Penyedia mengirimkan barang selambat-lambatnya lima hari kerja sejak tanggal transaksi untuk area Jabodetabek, sedangkan untuk area di luar Jabodetabek selambat-lambatnya dilakukan tujuh hari kerja sejak tanggal transaksi pada aplikasi e purchasing

Penyedia barang memberitahukan status pengiriman barang kepada PPK melalui aplikasi e purchasing. Panitia Pemeriksa Hasil Pekerjaan (PPHP) menerima dan melakukan pemeriksaan barang yang dikirimkan penyedia barang sesuai surat pesanan selambat-lambatnya lima hari kerja sejak barang diterima oleh pembeli, kecuali ditentukan lain dalam surat perjanjian.

Jika ditemukan kerusakan dan/atau ketidaksesuaian spesifikasi barang, maka PPHP menyampaikan pemberitahuan kerusakan dan atau ketidaksesuaian kepada PPK. Atas dasar pemberitahuan tersebut, PPK 
mengajukan permintaan penggantian dengan melampirkan Berita Acara Pemeriksaan Hasil Pekerjaan (BPHP) kepada penyedia selambat-lambatnya tiga hari kerja sejak tanggal penerimaan barang. Penggantian barang juga dapat dilakukan setelah penandatanganan Berita Acara Serah Terima Pekerjaan (BAST) apabila ditemukan bahwa barang tidak berfungsi atau tidak sesuai spesifikasi. Penggantian barang selambat-lambatnya empat belas hari kerja sejak tanggal BAST ditandatangani. Setelah pekerjaan selesai dilaksanakan, PPK membuat status penerimaan barang kepada penyedia barang melalui aplikasi e purchasing.

Pembayaran dilakukan setelah Panitia Penerima Hasil Pekerjaan (PPHP) menerima barang dimana barang tersebut sudah sesuai spesifikasi barang yang dipesan dan dibuktikan dengan penandatanganan BAST oleh PPHP dan penyedia barang. Penyedia menerbitkan kuitansi/bukti pembayaran atas pembelian barang atas nama dan ditujukan kepada PPK untuk dilakukan pembayaran atas tagihan pembelian barang tersebut. Kuitansi dipindai dan diunggah pada aplikasi e purchasing. PPK melakukan pembayaran selambatlambatnya lima belas hari kerja setelah PPK menilai bahwa dokumen pembayaran sah dan lengkap. PPK membuat status penerimaan barang melalui aplikasi e purchasing. PPK memasukkan data pembayaran ke dalam aplikasi e purchasing.

Pelaksanaan pengadaan barang/jasa pemerintah dengan e katalog akan lebih terbuka, transparan dan efisien dengan memangkas proses dan waktu dalam pengadaan barang/jasa pemerintah. Sebagai contoh untuk pengadaan obat-obatan, bahan medis habis pakai dan alat kesehatan oleh fasilitas kesehatan milik pemerintah yang melakukan pembelian melalaui e katalog dapat dilakukan dengan cepat dan efisien. Jika sebelumnya pada pelaksanaan pengadaan alat kesehatan melalui lelang banyak terjadi korupsi dan penyimpangan, dengan sistem e katalog hal tersebut dapat dihindari. 
Pengadaan alat kesehatan sangat rawan dan rentan akan korupsi, mengingat anggaran yang tersedia dalam pengadaan alat kesehatan yang besar.

Berdasarkan Laporan Tahunan Indonesian Corruption Watch (ICW) Tahun 2013, ditemukan indikasi kerugian negara dalam pengadaan alat kesehatan di Provinsi Banten dan Kota Tangerang Selatan. Dari total 78 paket pengadaan alat kesehatan TA 2012 dan 2013 senilai Rp 407 miliar diindikasikan kerugian negara sebesar Rp 132 miliar (Laporan Tahunan ICW 2012). Penelusuran tersebut sejalan dengan hasil audit BPK pada Laporan Keuangan Provinsi Banten dan Kota Tangeran Selatan TA 2012 yang juga ditemukan indikasi kerugian negara sebesar Rp 61 miliar lebih dan diduga proyek ini juga dimenangkan oleh perusahaan milik keluarga Ratu Atut dan kroninya (Laporan Tahunan ICW 2013). Sehingga setidaknya dalam proyek pengadaan alat kesehatan di Provinsi Banten dan Kota Tangerang Selatan TA 2012 - 2013 indikasi kerugian negara mencapai Rp 193 miliar (Bongkar Perkara Korupsi Alat Kesehatan Provinsi Banten dan Kota Tangerang Selatan). 7

Fasilitas kesehatan milik pemerintah tersebut tidak perlu melakukan lelang yang memakan waktu relatif lebih lama. Fasilitas kesehatan tersebut cukup memilih obat obatan, bahan medis habis pakai dan alat kesehatan langsung ke daftar barang di e katalog. Harga dan produk yang ditawarkan di e katalog juga sudah terstandar dan harga yang lebih murah dan bervariasi sehingga memudahkan fasilitas kesehatan memilih produk sesuai dengan harga dan kebutuhannya. Pengadaan barang/jasa melalui sistem e katalog ini mampu menekan efisiensi dan menghilangkan korupsi pengadaan barang/jasa pemerintah di sektor alat kesehatan ini yang sebelumnya sering terjadi pada saat pengadaan barang/jasa dilaksanakan melalui lelang.

7 William Christiawan "Analisa Kasus Korupsi Pengadaan Alat KesehatanDi Provinsi Banten Dan Kota Tangerang Selatan”, Jurnal Akuntansi Bisnis, Vol. XIV No. 28 Maret 2016, Universitas Katolik Sugijapranata, 2016, Semarang, hal 132. 


\section{Pengaruh Pelaksanaan E Katalog Dalam Pengadaan Barang/Jasa Pemerintah Terhadap UMKM}

Peran usaha mikro, kecil dan menengah (UMKM) dalam perekonomian Indonesia paling tidak dapat dilihat dari: (1) kedudukannya sebagai pemain utama dalam kegiatan ekonomi di berbagai sektor, (2) penyedia lapangan kerja yang terbesar, (3) pemain penting dalam pengembangan kegiatan ekonomi lokal dan pemberdayaan masyarakat, (4) pencipta pasar baru dan sumber inovasi, serta (5) sumbangannya dalam menjaga neraca pembayaran melalui kegiatan ekspor. ${ }^{8}$ Tidak dapat dipungkiri bahwa UMKM mempunyai peran yang sangat besar dalam perekonomian di Indonesia, idealnya UMKM mendapatkan perhatian yang besar dari pemerintah. Berpihaknya pemerintah terhadap UMKM disamping akan menggerakkan roda perekonomian secara cepat dan luas mengingat banyak unsur yang terlibat didalamnya. UMKM termasuk golongan usaha yang relatif lebih tahan krisis dibandingkan dengan pengusaha besar.

Hal yang menyebabkan UMKM lebih tahan krisis dibanding dengan perusahaan besar yaitu, umumnya UMKM menghasilkan barang konsumsi dan jasa yang dekat dengan kebutuhan masyarakat, pendapatan masyarakat yang merosot ketika krisis ekonomi terjadi tidak berpengaruh banyak terhadap permintaan barang dan jasa yang dihasilkan UMKM. Ini berbeda dengan kondisi usaha skala besar yang justru bertumbangan saat krisis terjadi. UMKM malah bisa tetap mampu bergerak dan menyerap tenaga kerja meski jumlahnya terbatas. Faktor kedua yakni pelaku usaha UMKM umumnya memanfaatkan sumber daya lokal, baik itu untuk sumber daya manusia, modal, bahan baku, hingga peralatan. Artinya, sebagian besar kebutuhan UMKM tidak mengandalkan barang impor. Faktor ketiga, umumnya bisnis UMKM tidak

${ }^{8}$ Adnan Husada Putra, "Peran UMKM dalam Pembangunan dan Kesejahteraan Masyarakat Kabupaten Blora”, Jurnal Analisa Sosiologi Vol 5 No 2 Oktober 2016, Universitas Sebelas Maret, 2016, Surakarta, hal 44.

DOI: https://doi.org/10.20961/jas.v5i2.18162 
ditopang dana pinjaman dari bank, melainkan dari dana sendiri. Dengan kondisi itu, ketika sektor perbankan terpuruk ataupun suku bunga melambung tinggi. ${ }^{9}$

Pemberdayaan masyarakat dalam ekonomi rakyat memang perlu menjadi perhatian kita bersama, terutama dalam masa-masa sekarang ini, di mana masyarakat menjadi semakin dituntut untuk aktif berperan dan bekerja lebih keras untuk memenuhi kebutuhan hidup sehari-hari. Baik laki-laki maupun perempuan dituntut untuk dapat mencari peluang dan kesempatan agar dapat berkarya dan berkreasi, sekaligus untuk memenuhi kebutuhan. Usaha Kecil Menengah yang sekarang mulai berkembang di Indonesia dan tumbuh pesat jumlahnya semenjak krisis ekonomi tahun 1997-an. Dimana banyak terjadi PHK oleh industri-industri menengah dan besar akibat krisis yang berkepanjangan. Banyak orang yang di PHK akhirnya mengembangkan usaha secara mandiri baik membuka usaha penjualan, pengolahan maupun jasa. ${ }^{10}$

Menurut Undang-Undang Nomor 20 Tahun 2008 tentang Usaha Mikro Kecil dan Menengah,UMKM terbagi menjadi 3 golongan yaitu a) usaha mikro yang mempunyai kekayaan paling banyak Rp. 50.000.000,- (lima puluh juta) atau mempunyai hasil penjualan tahunan paling banyak Rp 300.000.000,- (tiga ratus juta rupiah). b) usaha kecil yang mempunyai kekayaan antara Rp 50.000.000,- sampai dengan $\mathrm{Rp} 500.000 .000,-$ atau mempunyai hasil penjualan lebih dari Rp. 300.000.000,- sampai dengan Rp 2.500.000.000,- c) usaha menengah yaitu usaha ekonomi produktif yang berdiri sendiri, yang dilakukan oleh orang perorangan atau badan usaha yang bukan merupakan anak perusahaan atau cabang perusahaan yang dimiliki, dikuasai, atau menjadi bagian langsung maupun tidak langsung dengan Usaha Kecil atau Usaha Besar dengan jumlah kekayaan bersih lebih dari Rp 500.000.000,- (lima ratus juta rupiah) sampai dengan paling banyak Rp 10.000.000,- (sepuluh milyar rupiah)

${ }^{9}$ https://ekonomi.kompas.com/read/2012/03/28/11093274/Tiga.Hal.yang. Buat.UMKM. Tahan.Krisis, diunduh 7 Maret 2020 pukul 14.50 WIB.

${ }^{10}$ Sri Wahyuningsih, "Peranan UKM Dalam Perekonomian Indonesia”, Jurnal Mediagro Vol 5 No 1, Universitas Wahid Hasyim, 2009, Semarang, hal 2. 
tidak termasuk tanah dan bangunan tempat usaha; atau memiliki hasil penjualan tahunan lebih dari Rp 2.500.000.000,- (dua milyar lima ratus juta rupiah) sampai dengan paling banyak Rp 50.000.000,- (lima puluh milyar rupiah)

Dilihat dari penggolongan UMKM tersebut dapat disimpulkan bahwa golongan UMKM sangat luas dan mempunyai kontribusi yang besar terhadap pembangunan ekonomi Indonesia. Penggolongan tersebut juga dapat dianalisis bahwa UMKM mempunyai peran dominan dan mayoritas pengusaha di Indonesia adalah UMKM. Walaupun jumlah UMKM mendominasi, tetapi hal tersebut tidak diikuti dengan tingginya modal dan asset yang dimiliki oleh UMKM. Konglomerasi masih mendominasi dengan mempunyai kekuatan modal dan asset yang cukup besar dibandingkan dengan UMKM. Pengusaha besar atau konglomerat banyak didukung pemerintah dalam melakukan pengembangan usahanya baik melalui kemudahan akses perbankan maupun kebijakan pemerintah yang menguntungkan perusahaan besar. Tak heran jika ada pengusaha besar yang bergerak di industri rokok sekarang ini mempunyai banyak usaha baik di sektor perbankan, perkebunan, properti bahkan pertambangan. Jika sektor UMKM kurang mendapatkan perhatian yang besar dari pemerintah, sehingga UMKM akan semakin tertinggal dengan pengusaha besar.

Peran masyarakat dalam pembangunan nasional, utamanya dalam pembangunan ekonomi adalah Usaha Mikro, Kecil, dan Menengah. Posisi Usaha Mikro, Kecil, dan Menengah (UMKM) dalam perekonomian nasional memiliki peran yang penting dan strategis. Kondisi tersebut sangat memungkinkan karena eksistensi UMKM cukup dominan dalam perekonomian Indonesia, dengan alasan jumlah industri yang besar dan terdapat dalam setiap sektor ekonomi; potensi yang besar dalam penyerapan 
tenaga kerja, dan kontribusi UMKM dalam pembentukan Produk Domestik Bruto (PDB) sangat dominan. ${ }^{11}$

Pelaksanaan pengadaan barang/jasa pemerintah melalaui e katalog diharapkan tidak semakin "membunuh" sektor UMKM dalam pertisipasinya untuk mengikuti pengadaan barang/jasa pemerintah. Data dari Gapensi Kota Semarang tahun 2019 menyebutkan bahwa jumlah penyedia barang yang sebaran kualifikasi badan usahanya sebagai berikut: kualifikasi besar 2 sebanyak 0,3\% atau 1 penyedia barang dan jasa, besar 1 sebanyak $3.4 \%$ atau 12 penyedia barang dan jasa, menengah 2 sebanyak $5.7 \%$ atau 20 penyedia barang dan jasa, menengah 1 sebanyak $13.2 \%$ atau 46 penyedia barang dan jasa, kecil 3 sebanyak $18.7 \%$ atau 65 penyedia barang dan jasa, kecil 23 sebanyak $6.6 \%$ atau 1 penyedia barang dan jasa, kecil 1 sebanyak $52.0 \%$ atau 181 penyedia barang dan jasa. Dari penggolongan tersebut dapat dilihat bahwa UMKM mendominasi jumlah penyedia barang/jasa pemerintah lebih dari angka 95\%, tetapi hal tersebut tidak berbanding lurus dengan partisipasi penyedia barang/jasa di golongan UMKM dalam partisipasinya mengikuti pengadaan barang/jasa pemerintah.

Presiden Joko Widodo dalam arahannya kepada LKPP agar dapat mefasilitasi UMKM untuk dapat berpartisiapasi aktif dalam e katalog. Mendorong UMKM mendapatkan kemudahan lewat kebijakan dari pemerintah agar produk-produk lokal hasil produksi dari UMKM dapat bersaing dengan produksi luar negeri. Jangan sampai produk luar negeri masuk e katalog dengan mendompleng nama dari UMKM. Tidak dapat dipungkiri ada bebearapa pengusaha kecil yang "nakal" dengan mendatangkan produk impor kemudian diberikan label sebagi produksi UMKM. Ditemukannya cangkul impor yang mendominasi perdaganagn cangkul di Indonesai menunjukkan

${ }^{11}$ Sudati Nur Sarfiah, Hanung Eka Atmaja, Dian Marlina Verawati, "UMKM Sebagai Pilar Membangun Ekonomi Bangsa”, Jurnal Riset ekonomi Pembangunan (REP) Vol 4 No 1, Universitas Tidar, 2019, Magelang, hal 138. 
bahwa Indonesia sangat lemah dalam perlindungan dan pengembangan usaha terhadap UMKM.

Perlu adanya standarisasi dari pemerintah melalui Kementerian Perindustrian, Kementerian Koperasi dan UMKM dan Kementerian Perdagangan agar bersinergi dalam mengembangkan industri dan usaha kecil dari UMKM agar dapat berkembang dan masuk e katalog. Adanya standarisasi dari instansi berwenang tentunya akan menghambat produk impor membanjiri pasar Indonesia, sebagai contoh penerapan Tingkat Komponen Dalam Negeri (TKDN) akan membantu produksi dalam negeri bersaing dengan produk impor. Pemberlakuan TKDN bagi produk-produk yang masuk di e katalog akan memudahkan UMKM dalam memasarkan produknya di e katalog. Masuknya produkdari UMKM ke e katalog akan meningkatkan omzet dan semakin berkembangnya UMKM. Berkembangnya UMKM akan berdampak positif bagi perekonomian Indonesia, banyaknya tenaga kerja yang terserap di sektor UMKM akan mengurangi pengangguran dan meningkatnya daya beli masyarakat.

Pelaksanaan e katalog dalam pengadaan barang/jasa pemerintah berpengaruh pada sektor UMKM, masih adanya pelaku industri kecil yang selama ini menjadi rantai distribusi barang/jasa. Melalui e katalog yang memutus rantai distribusi tersebut menyebabkan terhapusnya peran penyedia jasa kecil yang selama ini menjadi bagian dari rantai distribusi. Penyedia jasa kecil atau UMKM yang hanya berperan sebagai rantai distribusi saja dalam proses pengadaan barang/jasa pemerintah akan mati dengan pemberlakuan sistem e katalog. Pejabat Pembuat Komitmen selaku pengguna barang sengan sistem e katalog dapat langsung melakukan pembelian kepada pabrikan dan atau distributor besar yang mempunyai jaringan.

Adanya perhatian dan kebijakan pemerintah yang memihak pada UMKM dalam proses pengadaan barang/jasa pemerintah akan berpengaruh pada eksistensi UMKM. Sehingga kebijakan pemerintah dalam mendorong 
UMKM agar produknya dapat mengikuti e katalog mempunyai arti penting bagi UMKM itu sendiri. Terbukanya pola kemitraan dalam proses pengadaan barang/jasa pemerintah juga sebagai salah satu bukti adanya perhatian pemerintah pada UMKM. Hal tersebut sesuai dengan Pasal 7 Ayat 1 (satu) Undang-Undang Nomor 20 Tahun 2008 tentang Usaha Mikro Kecil dan Menengah, yang mengamanatkan kepada pemerintah dan pemerintah daerah menumbuhkan iklim usaha dengan menetapkan peraturan perundangundangan dan kebijakan yang salah satunya meliputi aspek kemitraan. Begitu pula dalam pelaksanaan e katalog yang mendukung keberadaan produk UMKM di e katalog tetapi juga sektor lain termasuk sektor jasa.

Sebagai contoh untuk pengadaan komputer dan printer di daerah, penyedia jasa besar yang memperoleh kontrak pembelian melalaui e katalog dapat bekerja sama dengan pola kemitraan dengan penyedia jasa lokal. UMKM dapat berperan serta baik melalui jasa pemngiriman atau sebagai mitra dalam service centre dalam pengadaan komputer tersebut. Terjalinnya kemitraan antara penyedia jasa dengan UMKM akan memberikan nilai lebih, karena ada layanan purna jual yang berdomisili di daerah pengguna barang sehingga dapat memberikan pelayanan yang cepat, murah dan efisien tanpa harus mengirim barang yang rusak ke lokasi penyedia jasa.

Adanya kemudahan yang diberikan oleh pemerintah melalaui UMKM yang mempunyai produk untuk dapat terdaftar di e katalog sedikit banyak dapat membantu eksistensi UMKM. Salah satunya pemerintah juga telah mendorong produk UMKM bisa terdaftar dalam e katalog lokal. Agar dapat eksis dan bersaing UMKM dituntut untuk selalau kreatif dan inovatif dalam menghasilkan dan mengembangkan suatu produknya. Selain itu pemerintah melalui LKPP juga harus dapat berperan aktif membina UMKM agar dapat berperan serta dalam e katalog. Minimnya modal dan masih terbatasnya pengetahuan dari UMKM akan sistem e katalog juga menjadi salah satu faktor 
masih minimnya UMKM berpartisipasi dalam sistem e katalog dalam pengadaan barang/jasa pemerintah.

\section{E. PENUTUP}

Pelaksanaan pengadaan barang/jasa pemerintah dengan e katalog akan lebih terbuka, transparan dan efisien dengan memangkas proses dan waktu dalam pengadaan barang/jasa pemerintah. Sebagai contoh untuk pengadaan obat-obatan, bahan medis habis pakai dan alat kesehatan oleh fasilitas kesehatan milik pemerintah yang melakukan pembelian melalaui e katalog dapat dilakukan dengan cepat dan efisien. Jika sebelumnya pada pelaksanaan pengadaan alat kesehatan melalaui lelang banyak terjadi korupsi dan penyimpangan melalui sistem e katalog, hal tersebut dapat dihindari.

Pelaksanaan e katalog dalam pengadaan barang/jasa pemerintah berpengaruh pada sektor UMKM, masih adanya pelaku industri kecil yang selama ini menjadi rantai distribusi barang/jasa. Melalui e katalog yang memutus rantai distribusi tersebut menyebabkan terhapusnya peran penyedia jasa kecil yang selama ini menjadi bagian dari rantai distribusi. Penyedia jasa kecil atau UMKM yang hanya berperan sebagai rantai distribusi saja dalam proses pengadaan barang/jasa pemerintah akan mati dengan pemberlakuan sistem e katalog. Pemerintah telah mendorong pemanfaatan sistem e katalog bagi UMKM, salah satunya adalah partisipasi UMKM dalam produk lokal e katalog. Pada pelaksanaanya pemanfaatan sistem e katalog bagi UMKM masih kurang, terbukti dengan masih minimnya pemanfaatan sistem e katalog dalam pengadaan barang/jasa pemerintah oleh UMKM karena masih terbatasnya modal dan informasi terkait penggunaan sistem e katalog.

Perlu adanya peran aktif dan sinergi dari pemerintah melalui LKPP untuk kebijakan dan pengembangan informasi e katalog bagi UMKM. Kementerian Perindustrian perlu mengembangkan kebijakan terkait Tingkat Penggunaan Komponen Dalam Negeri (TKDN) dan bersama Kementerian Koperasi dan UMKM, Kementerian Perdagangan mengembangkan dan membina UMKM 
agar dapat berinovasi dan kreatif dalam menghasilkan produknya sehingga dapat memenuhi standar yang ditentukan untuk dapat masuk e katalog. Kementerian Perdagangan perlu melakukan pengawasan yang ketat terhadap produk impor yang berganti label menjadi produk lokal sehingga dapat merugikan UMKM dan pemerintah. UMKM sendiri agar dapat melakukan inovasi dan kreatif dalam pengembangan produk sehingga dapat mengahsilkan produk yang berkaulitas dan murah sehingga dapat bersaing di pasar global dan tidak hanya mengandalkan e katalog.

\section{DAFTAR PUSTAKA}

\section{BUKU}

Soerjono Soekamto, Pengantar Penelitian Hukum, UI-Press, 2006, Jakarta.

\section{JURNAL}

Adnan Husada Putra, "Peran UMKM dalam Pembangunan dan Kesejahteraan Masyarakat Kabupaten Blora", Jurnal Analisa Sosiologi Vol 5 No 2 Oktober 2016, Universitas Sebelas Maret, 2016, Surakarta, hal 44. DOI: https://doi.org/10.20961/jas.v5i2.18162

Amelia Iftitah Damayanti, Tjahjanulin Domai, Abdul Wachid, "Penerapan EProcurement Dalam Proses Pengadaan Barang/Jasa Di Kabupaten Malang”, Jurnal Administrasi Publik (JAP), Vol 1, No.2, Universitas Brawijaya, 2013, Malang.

Nuryanti, "Peran E-Commerce Untuk Meningkatkan Daya Saing Usaha Kecil Dan Menengah (UKM)”, Jurnal Ekonomi Volume 21, Nomor 4 Desember 2013, Universitas Riau, 2013, Pekanbaru.

Rio Pinondang Hasibuan, "Pengadaan Barang Dan Jasa Secara Elektronik Pada Dinas Koperasi Dan Umkm Kota Pekanbaru Tahun 2014”, Jurnal Online Mahasiswa (JOM) JOM FISIP Vol. 3 No. 2 - Oktober 2016, Fakultas Ilmu Sosial dan Ilmu Politik Universitas Riau, 2016, Pekanbaru.

Sri Wahyuningsih, "Peranan UKM Dalam Perekonomian Indonesia", Jurnal Mediagro Vol 5 No 1, Universitas Wahid Hasyim, 2009, Semarang.

Sudati Nur Sarfiah, Hanung Eka Atmaja, Dian Marlina Verawati, "UMKM Sebagai Pilar Membangun Ekonomi Bangsa", Jurnal Riset ekonomi Pembangunan (REP) Vol 4 No 1, Universitas Tidar, 2019, Magelang.

William Christiawan "Analisa Kasus Korupsi Pengadaan Alat KesehatanDi Provinsi Banten Dan Kota Tangerang Selatan”, Jurnal Akuntansi 
Bisnis, Vol. XIV No. 28 Maret 2016, Universitas Katolik Sugijapranata, 2016, Semarang.

Zaenal Arifin, "Tindak Pidana Korupsi Dalam Proses Pengadaan Barang Dan Jasa Pemerintah", Jurnal Respnsif Vol 5 No.5, Universitas Pembangunan Panca Budi, 2017, Medan.

\section{UNDANG-UNDANG}

Undang-Undang Nomor 20 Tahun 2008 tentang Usaha Mikro Kecil dan Menengah,UMKM

Peraturan Presiden No 54 Tahun 2010 tentang Pengadaan Barang/Jasa Pemerintah

Peraturan Presiden Nomor 4 Tahun 2015 tentang Perubahan Keempat Peraturan Presiden No 54 Tahun 2010 tentang Pengadaan Barang/Jasa Pemerintah

Peraturan Presiden Nomor 16 Tahun 2018 tentang Pengadaan Barang/Jasa Pemerintah

Peraturan Lembaga Kebijakan Pengadaan Barang/Jasa Pemerintah (LKPP) Nomor 11 Tahun 2018 Tentang Katalog Elektronik

\section{Internet}

https://analisadaily.com/berita/arsip/2017/10/28/440900/penerapan-e-katalogberdampak-pada-pelaku-usaha/

https://ekonomi.kompas.com/read/2012/03/28/11093274/Tiga.Hal.yang.Buat. $\underline{\text { UMKM.Tahan.Krisis }}$ 